\title{
A Memory Sterilized, Utilized, and Realized
}

\author{
William Robison \\ Faculty Mentors: Dr. David Pace and Dr. Edward Linenthal, Department of History, \\ Indiana University Bloomington
}

\begin{abstract}
After the French suffered a humiliating defeat in the Franco-Prussian War, the conditions in France were such that a proletarian uprising proved imminent. These volatile conditions, the famine, indebtedness, and national shame of the loss to Prussia, resulted in the formation of the Paris Commune in 1871. The Commune's abortive existence shocked Europe, and it generated highly charged opinions throughout the continent, from the poorest laborers to the wealthiest nobles. The effect of the Commune on continental political movements was particularly divergent as men and women continued to grapple with the memory and determined for themselves how best to render it intelligible. Some decided to pacify the memory, preaching of heroism and class struggle rather than violent revolution and anarchy. Others decided to utilize the memory of the Commune to incite revolts and strikes while others worked to realize the Commune's mission by following tangible lessons from the Communards. This paper demonstrates the numerous occasions in which the Commune was critically remembered and showcases the diverse effects of that memory's use by focusing on late 19th and early 20th century French revisionism, Dutch, Belgian, and Spanish revolts, and the Russian Revolution of 1917 (among other movements). It also places the Commune into a contemporary understanding by analyzing it within the frames of the wider academic literature on memory and of the recent French yellow-vest protests.
\end{abstract}

KEYWORDS: Paris Commune, socialism, Marxism, memory, Franco-Prussian War

\section{INTRODUCTION}

$\mathrm{T}$ The establishment of the Commune of Paris, following a bloody civil war that caused a profound loss of life along with the destruction of much of Paris, was one of the most memorable events of the late nineteenth century. Europeans across the continent had many different reactions, with some fearful of the possibility of a larger proletarian uprising, and others proud of the Communards for their valiant fight against the bourgeoisie and "undemocratic" principles. However, after the Commune's short, two-month hold on power, France did not experience any more large-scale violent labor uprisings. France had once been the primary hotbed of revolutionary movements, some major examples being the Revolution of 1793 and the June Days of 1848. However, it no longer seemed interested in violent liberal revolution. It even seemed to shy away from the idea of championing international revolution as it had in the past.

Even if the image and memory of the Paris Commune did not inspire radical upsurges in proletarian violence in the years after its fall, they did have a profound impact on the history of the European labor movement. It becomes important, then, to grasp the nuances and intricacies of how the memory of the Commune had a tangible effect on later labor movements throughout the continent. Memory, oftentimes, is not a recollection of the true events as they occurred. More often, it is a remembrance of the most pertinent qualities for a group at a specific time and under specific circumstances. The Commune provides a wonderful framework for analyzing just how memory changes over time and how it can differ based on the needs of both the individual and of the collective. In its most common uses, the memory of the Paris Commune served as a source of romantic spiritual maintenance, a catalyst for proletariat aggression, and as a blueprint for practical revolutionary tactics throughout Europe.

\section{BACKGROUND:}

\section{THE SEEDS OF REVOLUTION}

To best understand the basis for Revolution, the Franco-Prussian War of 1870 should be briefly touched upon. A balance-of-power political model (which, until after World War II, thoroughly guided most diplomatic decisions of European nations vis-à-vis their continental neighbors) had long kept France wary of a united Germany. However, the Prussian chancellor, Otto von Bismarck, worked tirelessly to navigate the political landscape of Europe to finally bring about a strong and centralized German Empire. The French worked to subvert the Prussians, and vice versa. What Bismarck needed most of all was a demonstration to the minor states of central Europe that strength could only be found in unity. Such a demonstration (and such an enemy) could easily be found in the leadership of Napoleon III and his Second French Empire. With tensions between the two nations already high due to an ongoing crisis of Spanish succession, Bismarck knew the political and social climate was finally ideal for German unification. To capitalize on the tense political environment, Bismarck sent a telegram to the French which could only be perceived as an insult to the French people. However, when the French reacted to it, the Prussians considered it an affront to Prussian (and wider German) prestige and honor. With this Ems Dispatch, Bismarck drastically increased public tensions between France and Prussia, leading Napoleon III to declare war on Prussia to rally public opinion in support of his Empire, which was faltering in popular support.

The war lasted less than a year, with Prussia routing the French on several occasions and generally proving far superior on the battlefield. Napoleon III fled the country in response to the humiliating defeats, leading to the collapse of the Second French Empire, the declaration of the Third Republic, and a humiliating Siege of Paris. The new republican government, centered in Versailles, quickly antagonized the working classes. The poor men and women of Paris were especially resentful of this new government, resulting in a massive uprising. A second government, the Parisian Commune, was formed on March 18,1871 on the foundation of true republicanism, as opposed to the veiled royalism present in the Versailles government. A civil war soon ensued, with troops loyal to the Versailles government and Communards fighting in the streets of Paris. Male and female Communards burned and looted buildings all throughout Paris as their defeat drew closer, causing resentment among the French moderates. On May 28, 1871, the Communards were defeated, and the movement was thoroughly driven out. Strict punishment and an intense cultural backlash against the Communards followed, 
especially against the women who were portrayed crudely by many French newspapers.

\section{MEMORY STERILIZED}

As previously mentioned, France did not experience any large-scale violent labor revolutions in the decades following the defeat of the Commune. This can largely be understood in the context of general European labor trends of the time. The French had developed "potent trade unions," and Marxist "revisionism" was becoming more popular as a method for enacting change. ${ }^{2}$ This movement towards gradualism and cooperation through existing government channels stood in stark contrast to the anarchic, violent, and thoroughly confusing ideology of the Commune. Evolutionary tactics began to come into style, with gradualism and cooperation within the French Left standing against what Henri Lefebvre deemed "revolutionary action." ${ }^{3}$ As such, the Commune was not seen as an appropriate example for rallying another revolution; the time for revolutions had come and gone. This is not to say that French leaders on the Left did not find a use for the memory of the Commune. The massive working class continued to hold onto the memory of the Commune, even if they did not apply it in a violent, tangibly aggressive manner.

French socialist leaders such as Louis Dubreuilh and Jean Jaurès (both of whom held positions writing for French socialist newspapers) used the Commune as a memory to organize and rally workers. Dubreuilh emphasized the valiant "heroism of individual Communards" to infuse the energy of the Communards' high-pitched struggle into the French Socialist Party. Without looking for tangible lessons from the Commune as a revolutionary precedent, he focused on the triumphant beginning rather than the "violent end" the men and women faced on the streets of Paris. ${ }^{4}$ Jaurès also focused on the "heroism of the Communards" and drew upon the rich "symboli[sm]" to commemorate the event and to instill hope into the French working class. ${ }^{5}$ For these leaders (and many more of the time), the Commune's memory was used to encourage the individual by solely focusing on the individual. One of these individuals, a famous female Communard named Louise Michel, was mentioned frequently at the annual commemorative marches to Père-Lachaise. Socialist leaders often spoke in romantic terms about the struggles and incredible will-power of Communards such as Michel to pay respect while maintaining distance from the Communards' more destructive and violent tendencies.

Despite the frequent references to the Commune in early French Socialist discourse, many leaders could not reconcile the cognitive inconsistency between their revisionist ideals and the Commune's dogmatic traits and violent tendencies. The annual marches to PèreLachaise were utilized by labor leaders to "recall 1871 as a tragedy" and give cause for somber remembrance rather than "collective action." 6 When the Russian peasantry organized for the December Uprising of 1905, French Socialist newspapers such as offered few connections between the Uprising and the Commune because of the continued desire to advocate "evolutionary thinking." Even decades after the fall of the Commune, French leaders feared the violent social repercussions that could follow if a popular resurgence in revolutionary tactics grew in France. More often than not, they preferred to use the Commune

\footnotetext{
Encyclopædia Britannica, 2019, s.v., "Franco-German War.” https://www.

britannica.com/event/Franco-German-War.

${ }^{2}$ Casey Harison, "The Paris Commune of 1871, the Russian Revolution of 1905, and the Shifting of the Revolutionary Tradition." History and Memory 19, no. 2 (2007):

5-42. doi:10.2979/his.2007.19.2.5., 7.

${ }^{3}$ Peter Starr, Commemorating Trauma: The Paris Commune and Its Cultural Aftermath (US: Fordham University Press, 2006b), 23.

${ }^{4}$ Harison, "The Paris Commune of $1871, " 10$

${ }^{5}$ Ibid, 12.

${ }^{6}$ Ibid, 17.
}

as a vague "symbol" whose grittier past was better "forgotten" and sterilized for public consumption.?

There were some French socialists who worked to portray the Commune in a more positive revolutionary light. One example of this was the moderate Edouard Vaillant, who "reveled in France's revolutionary past" and spoke in favor of strengthening class solidarity. A Communard himself, he energetically outlined the importance of unity in the socialist movement by fitting the Commune within the entire history of French revolutionary history, something Jaurès was not willing to do. ${ }^{8}$ Jaurès and Dubreuilh used the symbolism of the Commune as an isolated memory to energize the French socialist movement while Vaillant saw the Commune as the inevitable and wonderful culmination of decades of revolutionary tradition. However, neither side advocated for open revolution in their own time. They were intent on maintaining the revisionist status quo, working through the existing channels of the Third Republic to enact change through evolutionary tactics.

\section{MEMORY UTILIZED}

These moderate revisionists were not the only socialists in Europe, nor was the memory of the Commune confined to French territory. Karl Marx used the events of the Commune and the Franco-Prussian War that preceded it to write The Civil War in France in just under a month. The pamphlet, though hastily written, immediately assumed a vital role for socialists everywhere who opted to view the Commune as part of an integrated and continuing struggle against capitalism. Marx made his thoughts on the Commune's place in history clear when he closed the pamphlet with:

The soil out of which [the class struggle] grows is modern society itself. It cannot be stamped out by any amount of carnage. To stamp it out, the governments would have to stamp out the despotism of capital over labor - the condition of their own parasitical existence. Working men's Paris, with its Commune, will be forever celebrated as the glorious harbinger of a new society. Its martyrs are enshrined in the great heart of the working class. Its exterminators history has already nailed to that eternal pillory from which all the prayers of their priest will not avail to redeem them. ${ }^{9}$

Such a rousing memory at the end of an equally rousing chapter could only serve to increase the resolve of the working class to continue their struggle against perceived bourgeois oppression. As the most widely circulated source on the Parisian Commune, the emotionally charged text of The Civil War in France gave Marxian socialism a foothold for the first time in America and the Netherlands. In addition, new Italian, Spanish, and German translations made the legend of the Commune increasingly accessible across the continent. ${ }^{10}$ As the legend of the Commune spread, socialists across Europe were moved to follow Marx's rousing calls.

One area in which this call was clearly answered was in the Belgian town of Liège. In 1886, Belgian socialists prepared to commemorate the fifteenth anniversary of the fall of the Commune with a march, not unlike those annual marches to Père-Lachaise undertaken by the French socialists. The crowd of Belgian socialists was filled with men who desired radical change, and even women and children marched to honor those women and children who fought alongside their male compatriots. "Red flags" filled the air and proud speakers reminded the crowd of the sacrifices and heroism of the Communards and their fight

\section{Ibid, 23.}

${ }^{8}$ Ibid, $13-14$

${ }^{9}$ Karl Marx, "The Civil War in France." In Selected Works, Vol. 1, pp. 473-545. https://www.marxists.org/archive/marx/works/1871/civil-war-france/, (1958), Ch. 6, par. 47-48.

${ }^{10}$ Dennis Bos, "Building Barricades: The Political Transfer of a Contentious Roadblock." In the Euopean Review of History, 12:2, 345-365. doi: 10.1080/13507480500269183, (2006a), 350-351. 
for class equality. Unlike the relatively docile annual marches to PèreLachaise, however, this march became much more politically and emotionally charged. The crowd converged on the city center while "looting and fighting the police." The conflict eventually sparked even greater unrest, resulting in further "strikes and looting," increased clashes with the police, and more destruction. ${ }^{11}$ "With twenty-five dead, the insurgents had accomplished little more than adding the more immediate grief of their comrades' deaths to the overall tragedy of the French Commune.

Later that same year, a spontaneous proletariat insurrection broke out in Amsterdam, resulting in twenty-six deaths over two days of fighting against the military. Like Liège, Amsterdam was filled with red flags, but the Dutch also built barricades, a new development in the history of Dutch insurrection which intimately connected Amsterdam to the physical memory of the Paris Commune. The use of the barricade, popularized by the depictions of the Communards' romantic struggle, proved of little practical use to the Dutch. However, the inclusion of such an iconic symbol lent credence to the riot and placed it within the scope of a wider remembrance of the Paris Commune and socialism's constant march towards class solidarity and equality. ${ }^{12}$

Other nations utilized the cultural significance of the now legendary Parisian Commune as well, weaving their struggles into the emerging tapestry to honor the ongoing work of the European proletariat. In 1909, revolutionary fervor in Barcelona came to a head with a "fierce battle", later becoming known as the "Tragic Week" ("Semana Tragica"), alluding to the "Bloody Week" that corresponded with the fall of the Commune. ${ }^{13}$ In a fiery speech in 1908, Lenin attached the Russian December Uprising of 1905 to the Parisian Commune, foreshadowing the later relocation of revolutionary leadership from France to Russia. ${ }^{14}$ By utilizing the Paris Commune, movements could orient themselves within the shifting European political system, anchoring themselves to a foundation of distinctly leftist uprisings. The memory of the Commune served a direct role in bolstering the spirits of those men and women who fought against oppression. Additionally, it served to legitimize the movements that adopted the Commune's memory and hailed it as the inspiration for their struggle.

\section{MEMORY REALIZED}

However, none of the movements viewed their actions as a natural continuation of the actions of the Commune, Lenin being the exception. Rather, they used the Commune as a doorway into the international proletarian struggle. They were woven into the common tapestry of the Commune, viewing it as the torchbearer, but not the guide. The movements began to carry an international quality, an unsurprising development with the Commune itself including "revolutionary exiles" from Poland and "immigrant workers" from Belgium among its ranks..$^{15}$ As previously mentioned, Marx's literature on the French Civil War was translated and distributed widely, and Engels' added introduction in honor of the twentieth anniversary of the Commune describes the efforts of American socialists to "shake off the yoke" of aloof government and "political speculators." 16 The Commune began to be remembered simply within the context of a larger international history of labor resistance. Especially in France, the Revolution of 1789

\footnotetext{
${ }^{1}$ Ibid, 357

2 Ibid, 357-358

${ }^{3}$ Ibid, 358.

${ }^{4}$ Vladimir Lenin. "Lessons of the Commune." Zagranichnaya Gazeta, No. 2. In Lenin Collected Works vol. 13, 475-478 (1972). Moscow: Progress Publishers.

https://www.marxists.org/archive/lenin/works/1908/mar/23.htm\#fwV13E168, par. 10

${ }^{15}$ Bos, "Building Barricades," 354

${ }^{6}$ Marx, “The Civil War in France," Postscript, par. 13.
}

was still seen as the most important revolution of them all, and it was that original Revolution, not the Commune, which was the source of so many "historical analogies" for all aspiring political revolutions. ${ }^{17}$

Opposing this mode of thought, Lenin stood out among the revolutionaries of Europe primarily because of his insistence that the Commune deserved to be remembered not as a defeat, but rather as a spearhead for modern revolution. In his speech, "Lessons of the Commune," he outlined the mistakes of the Commune while suggesting how a revolution may succeed if socialists would heed the Commune's lessons of history. He goes on to show how those lessons were applied to the December Uprising of 1905. Critiquing the Communards, Lenin cites their lingering "patriotism" and their desire to "exert moral influence" as opposed to punishing the bourgeois class as a clear mistake. ${ }^{18}$ The Russian proletariat, he noted, was quick to shed patriotic allegiances and was not shy about direct, armed conflict with their enemies in order to attain their goals. In true consistency with his idea of each revolution building on the foundations of those prior, he looks ahead and predicts a larger uprising that will finally result in a proletariat "completely victorious."19

That foreshadowed conflict would become a reality with the October Revolution of 1917 and the subsequent Russian Civil War which ultimately resulted in Bolshevik control of Russia. It is of little surprise that one would look for similarities and common links between the Commune and October Revolution. Both were ultimately produced by the previous government's inability to wage an effective war, resulting in popular discontent and the eventual disintegration of the old regime. Each conflict eventually led to a battle between two governments, one parliamentarian and one revolutionary. The Russian parliamentary government, the Duma, was the result of the previous February Revolution of 1917, while the national French government at Versailles was popularly declared in the abdication of Napoleon III. For both the October Revolution and the Communards' uprising, the republican government predated the revolutionary government. Both involved outside interference, with Bismarck aiding the government in Versailles ${ }^{20}$ and Western European powers briefly aiding the monarchist White Army in Russia. ${ }^{21}$ While not carbon copies of each other, the similarities between the two events warranted a more serious consideration of the Commune and its role in guiding future socialist uprisings through tangible, historic lessons.

The Hungarians also staged a revolution of their own soon after, drawing on the memory of the Commune to work toward radical social change. With an economy racked by World War I, and a casualty count of up to "ninety percent of the armed forces" called to fight for the Austro-Hungarian Empire, the residents of urban centers such as Budapest were faced with uncertainty on all sides. Scarce food, declining real wages, and a housing shortage all culminated in the establishment of a National Council, a democratic republic that took power on October 31, 1918. ${ }^{22}$ However, the National Council was, for many reasons, an abject failure of a government. The lack of real elections, the inability to distribute land to the peasantry, and the inability to respond to foreign territorial demands crippled its chances of maintaining support. After a brief period of anarchy, the Hungarian Republic of Soviets was proclaimed, among promises of nationalization of key industries, resistance to the demands of the

\footnotetext{
Harison, "The Paris Commune of 1871," 20.

${ }^{18}$ Lenin, "Lessons of the Commune," par. 3 \& 6

${ }^{19}$ Ibid, par. 11

${ }^{20}$ Marx, "The Civil War in France," Ch. 6, par. 4.

${ }^{21}$ Katherine E. Ruiz-Díaz, "The Russian Civil War," Boston University, accessed

October 20, 2019, http://sites.bu.edu/revolutionaryrussia/student-research/ katherine-ruiz-diaz/.

${ }^{22}$ Istvan Deak, "Budapest and the Hungarian Revolutions of 1918-1919." The Slavonic and East European Review 46, no. 106: 129-40. http://www.jstor.org/ stable/4205930 (1968), 134.
} 
Entente powers, and support from the Russian army in securing peace for the nation. ${ }^{23}$

The new Republic, proclaimed after a commemoration of the Parisian Commune in Budapest, was fated to be short-lived. It only lasted 133 days before losing the faith of the workers and succumbing to counter-revolutionary pressure from the Entente and rural areas of Hungary. ${ }^{24}$ Among many factors, the most crucial errors of the Budapest Commune were the communists' "wild anti-religious propaganda" and the loss of urban support. ${ }^{25}$ It was hardly the glorious end that the Parisian Commune was so well known for, and the Hungarians ended where they began, with very little meaningful or lasting social change from either the National Council or the Budapest Commune. In stark contrast to the successful Russian revolution that preceded it, the Hungarian example demonstrates just how difficult it was to enact lasting socialist change in early twentieth century Europe, a lesson that the Parisian Communards also learned the hard way.

\section{THE IMPORTANCE OF MEMORY}

When looking at all the riots and revolutions that drew from the memory of the Commune, both directly and indirectly, the issue of how memory is (and was) utilized becomes integral to a fuller understanding of what all these events have in common. There are the obvious similarities, of course: the common use of the memory of the Commune, the proletariat nature of the movements, and the distinctly international quality of group. However, it is not entirely obvious why the Commune would be referenced and not the Revolution of 1789 which was successful in its attempt to oust the monarchy and, arguably, caused much more of a stir across Europe. The June Days of 1848, the result of a much shorter and less formalized ideological struggle, still inspired riots and monarchical panic for months to come, even causing some European leaders to take drastic action such as adopting constitutions and limiting their own power. The Commune, for all it did, lived on simply as a bad memory for the bourgeoisie. And unlike the June Days, it did not immediately inspire similar revolutions or Communes in surrounding nations.

\section{Why the Commune?}

As is evident, the Commune pales in comparison to the Revolution of 1789 and the June Days of 1848 in terms of its immediate effects on the European political climate. However, there are three arguments that could be made for why the Commune became so pivotal to so many disparate movements across generations and political boundaries. In one manner, it was exactly because the Commune was so chaotic and contradictory. Anarchists, socialists, communists, and all manner of other ideological representatives fighting against the Versailles government found common ground under the banner of the Commune. The ideas and visions of the Communards were often incongruous, and the form of government was such that primary leadership was impossible. The task they undertook turned from discussions of the future of their fledgling government toward arson in defense (and spite) against the Versailles army and Thiers. Because it was so historically messy, it was much easier to detach the legend of the Commune from what Eich Auerbach described as its "[material]... historical context". Without having produced something tangible and visible in a "definite domain", the event eludes "classification", and the contemporary minds of the age were free to use the memory as it suited them. ${ }^{26}$

\footnotetext{
${ }^{23}$ Ibid, 135-136.

${ }^{4}$ Bos, "Building Barricades," 358, and Deak, "Budapest and the Hugarian Revolutions," 137.

${ }^{25}$ Deak, 138.

${ }^{26}$ Starr, Commemorating Trauma, 1.
}

Secondly, legends serve a more cultural role; they may serve to strengthen the narrative of the speaker far better than dry discussions of facts and figures by tapping into subtle trends and even subtler cultural undercurrents and foundational "truths". Even Marx, who wrote on the history of the Commune in order to give the socialist movement a detailed, objective analysis of the event, did not refrain from adding emotionally charged passages. He could not help but add to the legend of the Commune through his villainization of the bourgeoisie and the heroism he attributed to the Communards. In addition, within his charged passages he touched on a new, bourgeoning cultural force that was emerging in Europe. Not confined to borders or states, class culture attached the legend of the Commune to the new, revolutionizing class. The French socialist leaders such as Edouard Vaillant and Louis Dubreuilh used the legend of the Commune to instill energy into their revisionist framework, drawing upon a culture which knew its place in the world very well. The French population Vaillant and Debreuilh reached were energized by their conception of carrying on the national mission of change, albeit in a more moderate manner. Lenin drew upon the culture of literature, drawing upon objective lessons and applying them to the Russian Uprising of 1905 and the later October Revolution of 1917. But even more than the objective lessons, Lenin used the legend to engage with more subtle cultural currents in the Russian peasant's growing class consciousness. He also used it to build the culture of the group that would, in time, dominate Europe's attention and triumph over the same tyranny the Communards failed against.

The third reason is that the collective memory of the Commune was flexible and changed over time. Through the various cultural metamorphoses and social events that Europe underwent over the span of many decades, the image of the Commune changed. Viewed through the eyes of a new generation, the place it held in French, Russian, and wider European societies moved and stretched into various forms.

Pierre Nora, in his article "Between Memory and History," gives stark importance to the issue of memory and its place in a society. "Memory is life," he writes, "borne by living societies," societies that change, grow, move, and possess a cultural memory. To survive, a culture may utilize memory insofar that it, unlike history, does not connect to the harsh past, but to the "eternal present," a view that connects the past with what is presently occurring. This may be seen in Lenin's work, fitting the memory of the Commune into the ongoing struggle for rights among Russia's lowest classes. The Commune was not used as a decades-ago symbol, rather, it was an extension of the present, a present that never ends, and a present that continues to live long after it has become "the past."

Nora writes that memory "only accommodates those facts that suit it," a clear reality for the use of the Commune as a collective memory. The French revisionists accommodated different facts about the Commune than the Dutch revolutionaries did. Both accommodated only those facts that lent credence to their movement, that of the Communards' brave struggle or of their violent means to an end. The "gigantic and breathtaking storehouse" that is memory is full of uncountable stocks: gestures and social structure, political action and social norms, individual reason, and collective madness. The Commune, an event molded and changed through the passage of time, was utilized in diverse events because it caused a shift, albeit a long-germinating one. It could be linked to an "eternal present," and its chaotic nature meant it could be used to encourage moderation, excess, and boldness under different circumstances. ${ }^{27}$

\footnotetext{
${ }^{27}$ Pierre Nora, "Between Memory and History: Les Lieux De Mémoire." Representations, no. 26 (1989): 7-24. doi:10.2307/2928520.
} 


\section{MEMORY'S PERSISTENCE}

Up until this point, the focus of this article has been on the use of memory as a catalyst for events in the nineteenth and twentieth centuries. The change over time, and across regions, may still seem detached from the contemporary world in which we live in. The Russian Revolution of 1917 largely superseded the Commune as a rallying point for proletariat uprising in the middle to late twentieth century. Even closer to the present day, global communism has collapsed with the fall of the Soviet Union, ground-breaking revolutions are largely absent in a world dominated by neoliberal ideology, and where there are riots (such as in Hong Kong, Chile, and the Middle East), the extent is largely localized. Does the Commune have any persisting relevance in the modern world?

To answer the question, it is again beneficial to turn to a more specialized definition of memory. Alon Confino describes collective memory in detail, and in his article "Collective Memory and Cultural History," he asserts that each "society sets up images of the past." The Commune, for Europeans in the nineteenth and twentieth centuries, was an image of the past which could be viewed from several different perspectives, as has been previously discussed. Confino goes on to write that for a "certain past" to be considered a mobilizing force, a viable and arguable source for social movement, it must "steer emotions [and] motivate people to act," meaning it must inspire and motivate..$^{28}$ To determine whether the Commune is relevant, as a "certain past" and as a memory utilized, to the modern world, examples of use (for inspiration, motivation, or both) should be present and obvious.

The bulk of contemporary uses of the memory of the Commune and the cultural foundations it left with its defeat are largely found in France. The diversity of Communards in the civil war of 1871 has an analogous element in the protests against the declaration of a state of emergency in France in 2016. Crowds took to the streets protesting against "strengthened security laws" in the face of ISIL killing 130 in Paris. There were a diverse mixture of men and women from varied backgrounds in the demonstrations; there were anarchists, an element that was also predominant in the Commune, undocumented migrant workers, some of whom would have been directly impacted by the raids and increased power the French government gave itself, and pro-Palestinian campaigners, concerned about what the government's stance would mean for Palestine's future. ${ }^{29}$ The cosmopolitan nature of the Commune has carried over into the modern world, having bled into French political culture partly thanks to the memory of the Commune.

There are also examples of the Commune's use as a specific memory utilized in French politics. The recent yellow-vest movement in response to reforms by French president Emmanuel Macron provide a wonderful source of investigation for similarities and direct reference to the Commune. For some, the barricades built on the avenues of Paris in 1871 have been compared to the modern barricades the yellowvests have erected in modern boulevards. Charged demonstrations of the Parisian working class include such events as yellow-jacket rioters walking through Père Lachaise Cemetery on their way to pay their respect at the Communards' wall. ${ }^{30}$ Macron's government has been depicted as standing against the interests of the average working Frenchman, a historical callback to the depiction of Thiers's government in Versailles as an enemy to the people.

To be transparent, the 1789 Revolution has been the main

\footnotetext{
${ }^{28}$ Alon Confino, "Collective Memory and Cultural History: Problems of Method." The American Historical Review 102, no. 5 (1997): 1386-403. doi:10.2307/2171069, 1390.

${ }^{29}$ Shafik Mandhai, "France state of emergency protest draws thousands.” Aljazeera News, 2016, https://www.aljazeera.com/news/2016/03/france-state-emergencyprotest-draws-thousands-160313030142388.html.

${ }^{30}$ Will Morrow, “'Yellow vest' protesters pay tribute at the Communards' Wall in Paris," World Socialist Web Site, 2019, https://www.wsws.org/en/ articles/2019/05/27/pari-m27.html.
}

political and cultural touchstone for these protests. It is a reference to "what every French citizen learns in school," and it is completely understandable that a more widely known and embraced historical event, especially one as iconic as the Revolution of 1789 , would be a rallying call for the French. Still, the notes of the Commune's presence are there. Some anti-authoritarian leftists in France have looked with scorn at the yellow-vest movement precisely because it is chaotic and messy. Some of the protesters uttered "racist and sexist slurs," while some called cops on "undocumented migrants." The movement grew to not only protests against increases in fuel taxes, but also to fight against "teaching staff cuts" and police brutality against high school aged protesters. Like the communards of 1871, the yellow-vest protesters have used the wider movement as a channel to express their own frustrations and demand changes to a system they perceive as unjust, unfair, and distant. In a way, the yellow-vests of the 2019 protests are analogous to the red flags the communards fought behind so long ago. ${ }^{31}$

The yellow-vests have also organized horizontally, rather than vertically. That is, they have "reclaimed politics" by moving away from "expert" guidance towards collective action. Theirs is a politics that moves beyond the "left-right" divide, and refuses to fall to either side of what they see as a "partisan" system that devalues their worth as citizens. The racist, anti-Semitic, and sexist elements that originally marred the movement (through negative media portrayals attempting to chalk the movement up to far-right, fascist violence) were gradually weeded out through such a system of horizontal selfpolicing. Now, lesbians and Muslims participate in the movement without fear of attack from within the yellow-vest movement, and without qualms about what they are fighting for. What they fight for is national recognition, a redistribution of power away from the hands of the elites, and a nation that they can live in as equal participants of the political culture. ${ }^{32}$ Like the Versailles government under Thiers, Macron's government has been branded as distant, aloof, and ignorant of the needs, desires, and dreams of the working-class French.

The Paris Commune, in all the different interpretations it has lived on through from the late nineteenth century to the present, cannot be separated from the movements it has inspired. Far from being forgotten, the memory of the Commune lives on even to this day, a strong testimony to the power the event holds for the working class, expressed both in direct references and in the analogous realities within movements such as the yellow-vest protests.

\section{CONCLUSION}

Whether used to bring spiritual maintenance, incite proletarian aggression, or serve as a model for political revolution, the Commune has served a key role in the modern European labor movement's memory. The French revisionists sterilized the memory of the Commune in order to bring about passive emotional support for the workers of France. They wrote and spoke avidly about the heroism of the Communards not to carry on the revolutionary tradition, but to gain support for their platform. However, once the international proletariat obtained the legend of the Commune, it was utilized to carry out petty riots and strikes in the name of socialism. They did not see their movements as the next step in progressing socialist ideals, but as necessary actions for the alleviation of their current oppression. Lastly, the Commune's legend was realized both positively, as in the case of the Russian Revolution of 1917, and negatively, as

\footnotetext{
${ }^{31}$ Zacharias Zoubir, "A Vest that Fits All.” Commune Magazine, issue 4, 2019, https://communemag.com/a-vest-that-fits-all/.

22 Benjamin Dodman, "A year of insurgency: How Yellow Vests left 'indelible mark' on French politics,” France24, 2019, https://www.france24.com/en/20191116-a-yearof-insurgency-how-yellow-vests-left-indelible-mark-on-french-politics.
} 
was the case for the Budapest Commune. These final movements were envisioned as carrying on the grand legacy of the socialist struggle that the Commune began, not simply to loot and kill, but to utterly destroy the bourgeois oppressors that had caused so much pain and suffering for the masses.

The memory of the Commune has also been utilized in recent years during several French movements and protests. While it has not retained a wide, international relevancy, it cannot be said to be dead or completely irrelevant. Like most memories, the memory of the Commune is referenced when it is most convenient for a social or cultural movement. Facts, legends, and semiotic connections (or cultural touchpoints) are used to give credence and wider importance to cultural and social variations and revolutions. In observing this, it can only be beneficial that more awareness is given to the importance of memory as it applies to diverse culture groups. The origin of memory in one culture or nation may potently and quickly bleed into the dominant or subversive narratives of other cultures and nations. Understanding how each individual in a culture is specifically and uniquely called to participate in the narrative of an ongoing memory (or the "eternal present"), is both intellectually rigorous and culturally necessary. It is intellectually rigorous in that the work is never really done, for memory influences individual actions constantly. It is culturally necessary, for without it, memory has a certain power over us, a power used for good and bad alike, and a people with no control over the cultivation and critique of their collective memory is a people lacking in direction.

\section{Footnote}

This article has been the beginning of a wider exposure to both European labor history and, perhaps more importantly, the wide literature on memory for me. There is still much for me to learn and much for me to comprehend on this subject specifically, and about memory more generally. As such, I fully understand that there are numerous ways in which to analyze the specifics of the Commune and the public memory of said event. There are always more scholarly articles, unique perspectives, and legitimate analyses to be uncovered. I hope with this article, more than anything, that others may become interested in what I have said in the space that was available to me. Knowledge only grows through cooperation and successive work, and this article is only a miniscule piece of a large (and growing) field of memory studies.

\section{ACKNOWLEDGEMENTS}

I would first like to thank Dr. Scott Libson for aiding me in finding sources for the beginning stages of my research. I would like to thank Professor Emeritus David Pace for inspiring me to continue looking into this topic and for being a source of encouragement in all my academic endeavors. In addition, I would like to thank Professor Edward Linenthal for his encouragement and insight, and for introducing me to the wider literature on memory studies that has been published in the past few decades. Lastly, I would like to thank my 2019 IFS classmates and our wonderful TA for their continued support, interest in anything and everything relating to Paris, and, most importantly, the dear memories that we share.

\section{AUTHOR INFORMATION}

All correspondence should be sent to the first author: william.c.robi6@gmail.com.

\section{BIBLIOGRAPHY}

Bos, Dennis. "Building Barricades: The Political Transfer of a Contentious Roadblock." In the Euopean Review of History 12 no. 2 (2006a): 345-365. doi: 10.1080/13507480500269183.

Confino, Alon. "Collective Memory and Cultural History: Problems of Method." The American Historical Review 102, no. 5 (1997): 1386-403. doi:10.2307/2171069.

Deak, Istvan. "Budapest and the Hungarian Revolutions of 19181919." The Slavonic and East European Review 46, no. 106 (1968): 129-40. http://www.jstor.org/stable/4205930.

Dodman, Benjamin. "A year of insurgency: How Yellow Vests left 'indelible mark' on French politics,” France24, 2019, https:// www.france24.com/en/20191116-a-year-of-insurgency-howyellow-vests-left-indelible-mark-on-french-politics.

Encyclopædia Britannica, s.v., "Franco-German War,” 2019, https://www.britannica.com/event/Franco-German-War.

Harison, Casey. "The Paris Commune of 1871, the Russian Revolution of 1905, and the Shifting of the Revolutionary Tradition." History and Memory 19, no. 2 (2007): 5-42. doi:10.2979/his.2007.19.2.5.

Lenin, Vladimir. "Lessons of the Commune." Zagranichnaya Gazeta, No. 2. In Lenin Collected Works, vol. 13 (1972): 475478. Moscow: Progress Publishers. https://www.marxists.org/ archive/lenin/works/1908/mar/23.htm\#fwV13E168.

Mandhai, Shafik. "France state of emergency protest draws thousands," Aljazeera News, 2016. https://www.aljazeera. com/news/2016/03/france-state-emergency-protest-drawsthousands-160313030142388.html.

Marx, Karl. The Civil War in France. In Selected Works, Vol. 1 (1958): 473-545. https://www.marxists.org/archive/marx/ works/1871/civil-war-france/.

Morrow, Will. "'Yellow vest' protesters pay tribute at the Communards' Wall in Paris," World Socialist Web Site, 2019 https://www.wsws.org/en/articles/2019/05/27/pari-m27.html.

Nora, Pierre. "Between Memory and History: Les Lieux De Mémoire." Representations, no. 26 (1989): 7-24. doi:10.2307/2928520.

Ruiz-Díaz, Katherine E. “The Russian Civil War,” Boston University. accessed October 20, 2019, http://sites.bu.edu/ revolutionaryrussia/student-research/katherine-ruiz-diaz/.

Starr, Peter. Commemorating Trauma: The Paris Commune and Its Cultural Aftermath. US: Fordham University Press, 2006b.

Zoubir, Zacharias. "A Vest that Fits All." Commune Magazine, issue 4, 2019. https://communemag.com/a-vest-that-fits-all/. 